\title{
P53 protein expression and cell viability in irradiated peripheral blood mononuclear cells as bioindicators of radiosensitivity
}

\author{
Mariana Brayner Cavalcanti ${ }^{1^{*}}$, Ana Paula Galvão da Silva ${ }^{1,2}$, Rafael de Freitas e Silva ${ }^{1}$, Ademir \\ Amaral $^{1}$ \\ ${ }^{1}$ Grupo de Estudos em Radioproteção e Radioecologia (GERAR), Laboratório de Modelagem e Biodosimetria Aplicada (LAMBDA), \\ Departamento de Energia Nuclear, Universidade Federal de Pernambuco, Cidade Universitária, Pernambuco, Brazil; \\ *Corresponding Author: maribrayner@yahoo.com.br \\ ${ }^{2}$ Anaptysbio Incorporation, Cell Biology, San Diego, USA.
}

Received 12 November 2010; revised 9 December 2010; accepted 22 December 2011.

\begin{abstract}
Cellular radiosensitivity is directly correlated with the mechanism of DNA repair, in which p53 protein plays a major role. In this context, this study correlated cell death with p53 expression in lymphocytes irradiated in vitro with different doses of gamma-radiation. For this, peripheral blood samples were collected from 10 healthy subjects. Each sample was divided in aliquots and, separately, irradiated with doses of $0.5 ; 2$ and $4 \mathrm{~Gy}$. After this, peripheral blood mononuclear cells (PBMCs) were isolated and cultivated during 72 hours in $5 \% \mathrm{CO}_{2}$ at $37^{\circ} \mathrm{C}$ without mitogen stimulation. The expression of p53 protein was evaluated by flow cytometry. In parallel, cell viability was determined by trypan blue staining. Statistical analysis was performed using analysis of variance (ANOVA), differences were considered as statistically significant when $p<0.05$. The results showed an increase of p53 expression with the absorbed dose, which was proportional to cell death, suggesting that p53 can be used as bioindicator of individual radiosensitivity.
\end{abstract}

Keywords: P53 Protein; Radiosensitivity; Lymphocytes; Flow Cytometry; Cell Viability

\section{INTRODUCTION}

About $50 \%$ of all cancer patients in the World undergo radiotherapy at some point of their treatment, being $60 \%$ of them treated with curative intent [1]. The invasive characteristic of cancer implies that target volume to be irradiated is generally outlined beyond the tumor boundaries, which leads to side effects of radiotherapy that are caused by damage of normal tissues. Therefore, in treatments of radioresistant tumors, connective tissue tolerance to irradiation has an important role in the protocol definition as well as for the effectiveness of radiotherapy.

It has been shown that even when submitted to similar protocols, patients differ widely in terms of normal tissue reactions after irradiation [2,3], approximately $80 \%$ of these differences cannot be explained by physical factors [4]. Post-irradiation side effects occur as a function of individual radiosensitivity, which is correlated with genetically determined intrinsic differences in the cellular and molecular response to the radio induced damage [4-6]. This feature was firstly emphasized from patients with rare genetic syndromes, related to mutations in genes involved in the detection and repair of DNA damage [7].

Depending on multiple factors, including source and extent of stress, DNA damage leads either to cell cycle arrest in which the cell is given the opportunity to repair damaged DNA or to the complete disposal of the cell by a process so-called apoptosis. Although the mechanisms responsible for this decision are still far from being elucidated, they are not mutually exclusive, being orchestrated by components that are critical for two processes: DNA repair and apoptosis [8-10].

After DNA damage, cellular decision is mediated by the expression of the p53 protein, which can modulate these events in a transcription-dependent and independent manner. Normally, p53 protein can be detected in the cell cytoplasm at small concentration and with a short average lifetime. However, when cells suffer the action of ionizing radiation (IR), an increase of p53 protein expression is observed as well as alterations in 
its conformational structure, increasing the protein mean life [11-14].

Recently, Cavalcanti et al. observed the rise of p53 protein expression with the absorbed dose in human lymphocytes. The authors suggested the evaluation of this protein, by Flow Cytometry (FC), as biomarker of individual exposure to IR [15]. In the last years, FC has been applied in fast evaluations of antigens located on the cell surface, cytoplasm or nucleus, in a large number of cells in short time. The use of FC to investigate cellular changes after exposure to ionizing radiation may constitute a fast and reliable method for individual monitoring in cases of accidental or suspected exposures to IR [14-16].

In this context, this work was designed to evaluate the expression of p53 protein as possible bioindicator of radiosensitivity based on in vitro irradiation of peripheral blood mononuclear cells with different doses of ${ }^{60} \mathrm{Co}$ gamma source.

\section{MATERIALS AND METHODS}

\subsection{Sampling and in Vitro Irradiation}

This work was priory approved by the Pernambuco Hemocenter Ethics Committee (Hemope Foundation, $\mathrm{N}^{\circ}$ 046/06). All participants signed an informed consent.

The study group consisted of 5 females (mean age, 29 years; range, 19 - 42) and 5 males (mean age, 30 years; range, 24 - 36). All donors were healthy individuals and known not to have used medication at the moment of blood collection and had never been submitted to sanguineous transfusion and radiotherapy. Samples containing $40 \mathrm{~mL}$ of peripheral blood were collected and divided into four aliquots of $10 \mathrm{~mL}$. Three aliquots were irradiated at room temperature using a ${ }^{60} \mathrm{Co}$ gamma source (Theratron 780 - Atomic Energy of Canadá Limited) with a dose-rate of $196.67 \mathrm{cGy}$.min ${ }^{1}$ delivering doses of $0.5,2$ and 4 Gy, respectively. Non-irradiated blood aliquot was used as control.

\subsection{Cell Culture}

After irradiation, peripheral blood mononuclear cells (PBMCs) were isolated by centrifugation (at $400 \mathrm{~g}$ for 35 min) using Ficoll Paque Plus (GE Healthcare, USA). PBMCs were washed twice in phosphate-buffered saline (PBS 0.1M, pH 7.2 - 7.4) and resuspended in RPMI1640 medium supplemented with $10 \%$ fetal bovine serum, $2 \mathrm{mM}$ - L- glutamine, $50 \mathrm{mg} / \mathrm{L}$ of sulphate gentamicine and $2 \mathrm{mg} / \mathrm{L}$ of amphotericin B (Cultilab, Brazil) at the density of $2 \times 10^{6}$ cells $/ \mathrm{ml}$. Cells were cultured in $96 \mathrm{U}$ bottom well culture plates (TPP, Switzerland) at a density of $2 \times 10^{5}$ cells $/$ well for 72 hours in $5 \% \mathrm{CO}_{2}$ at $37^{\circ} \mathrm{C}$. To each evaluated parameter, cultures were per- formed in triplicate.

\subsection{Cell Viability}

Cell viability was scored at time zero and 72 hours after culture using trypan blue dye $0.4 \%$ (Sigma-Aldrich, USA) at $1: 10$ dilution ( 1 part of cells: 9 parts of dye). Viable and non-viable cells numbers were determined using a hematocytometer by optical microscopy. Viability was calculated as follows: (\%) cell viability = total viable cells (unstained)/total cells (viable and non-viable cells) $\times 100$. Each analysis was performed in triplicate.

\subsection{Flow Cytometry}

Following 72 hours culture, all cells were harvested and washed with RPMI-1640 medium supplemented with $10 \%$ fetal bovine serum and re-suspended in permeabilizing solution $-1 \mathrm{~mL}$ of facs lysing solution (BD Pharmigen, USA), diluted water (1/10), per $9 \mathrm{~mL}$ of $4 \%$ paraformaldehyde in PBS - and incubated for $10 \mathrm{~min}$ at room temperature. After this period, cells were washed with PBS $0.05 \%$ Tween 20 (Merck, Germany) at $400 \mathrm{~g}$ for $5 \mathrm{~min}$. Cell pellet was resuspended in $200 \mu \mathrm{L}$ of PBS $0.05 \%$ Tween 20 (Merck, Germany) and stained with PE-conjugated anti-p53 antibody (clone G59-12) (BD Pharmigen, USA) for $20 \mathrm{~min}$ at room temperature. The cells were then washed twice in PBS $0.05 \%$ Tween 20 (Merck, Germany) and fixed with $500 \mu \mathrm{L}$ of $1 \%$ paraformaldehyde in PBS. PE conjugated mouse IgG1 (clone MOPC-21) (BD Pharmigen, USA) was used as isotype control antibody. Fluorescence intensity of 50,000 events was acquired through FACScalibur flow cytometer (Becton Dickinson, USA), equipped with a $15 \mathrm{~mW}$ argon-ion laser (wavelength $488 \mathrm{~nm}$ ). Data was processed using Cell Quest pro software (Becton Dickinson immunocytometry systems, USA).

\subsection{Statistical Analysis}

For this, it was performed using analysis of variance (ANOVA), differences were considered as statistically significant when $p<0.05$.

\section{RESULTS AND DISCUSSION}

The Figure 1 shows the percentage of viable PBMCs in non-irradiated and irradiated blood samples, emphasizing that the viability of PBMCs determined right after treatment with different absorbed doses did not differ from the total number of viable cells in non-irradiated cultures, suggesting that cell death induced by gamma radiation does not occur immediately. However, a decrease in cell viability was found in irradiated cells after 72 hours of culture, and it was directly proportional to 


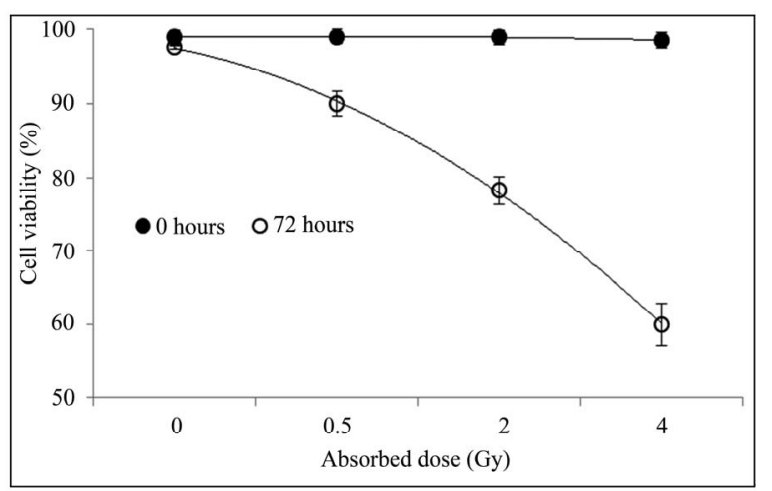

Figure 1. Percentage of viable cells in non-irradiated and irradiated PBMCs. Blood sample was divided into four aliquots of $10 \mathrm{~mL}$ each and irradiated with $0.5 ; 2$; and $4 \mathrm{~Gy}$; the remaining blood was used as non-irradiated control. Cellular viability was determined by trypan blue staining right after irradiation and $72 \mathrm{~h}$ after culture.

the absorbed dose. According to Boreham et al., the ionizing radiation induces apoptosis in lymphocytes, which increases with time after exposure up to 72 hours [17]. The decline in PBMCs viability after irradiation occurred probably due to cell death by apoptosis, as the latter is the dominant mode of radiation-induced cell-killing mechanism in human lymphocytes $[18,19]$, although we did not investigate apoptosis in this study. Trypan blue dye only stains cells that are already dead with plasmatic membrane damage (either by necrosis or apoptosis). Cells that are still undergoing the early events of death such as apoptosis cannot be identified using Trypan blue dye. Thus, further investigation of early and late phase of apoptosis is necessary to confirm this hypothesis.

The Figure 2 contrasts the percentage of viable PBMCs isolated from irradiated and non-irradiated blood samples from males and females subjects after 72 hours of cell culture.

Analyses of variance (ANOVA) of the cell viability in irradiated PBMCs isolated from blood samples of females and males subjects presented in the Figure 2, demonstrated that there are no statistically significant differences between the studied groups at the $99.5 \%$ confidence level, indicating that sensitivity of PBMCs to gamma radiation doesn't vary with gender. Borgmann et al. observed in literature remarkable differences in toxicity profiles after radiotherapy on clinical, molecular, and cellular levels between male and female [20]. However, further studies are required and should be focused on the aspect of individual radiosensitivity.

The Figure 3 presents the perceptual of cell viability and the expression of $\mathrm{p} 53$ protein in non-irradiated and irradiated lymphocytes (with doses: 0.5, 2 and 4 Gy).

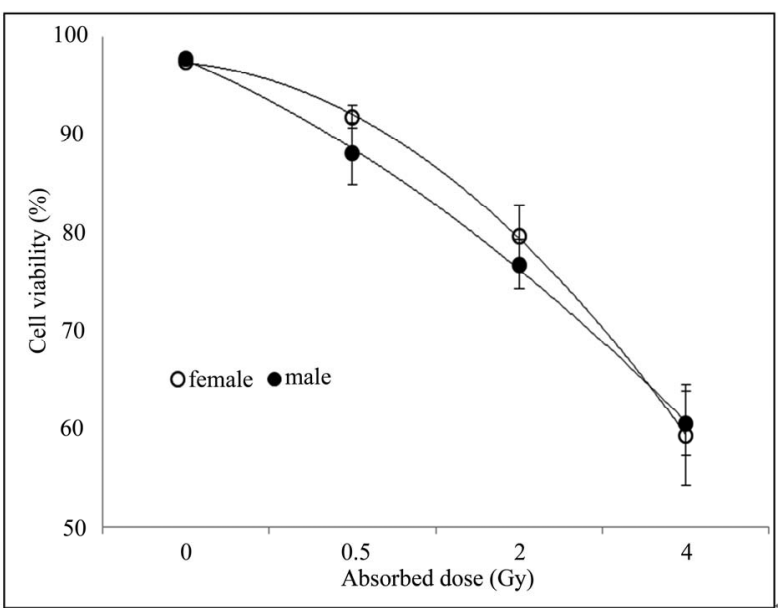

Figure 2. No difference was observed in cell viability of non-irradiated and irradiated PBMCs from female and male subjects. Blood sample was irradiated with 0.5 ; 2; and 4 Gy and the remaining was used as non-irradiated control. Cellular viability was determined by trypan blue staining right after irradiation and $72 \mathrm{~h}$ after culture.

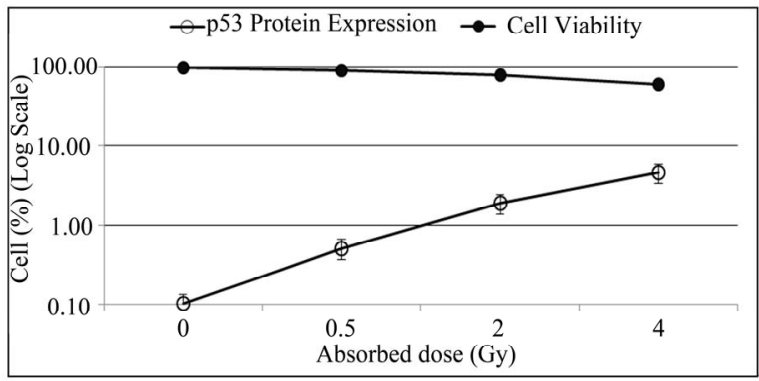

Figure 3. Expression of p53 protein in lymphocytes increases with absorbed dose and the cell viability decrease. PBMCs were isolated from irradiated and non-irradiated human peripheral blood and p53 expression was determined by flow cytometry $72 \mathrm{~h}$ after culture.

In this study, an increase in the levels of $\mathrm{p} 53$ protein expression was observed in irradiated PBMCs after 72 hours in culture with no stimulation, which is not found in non-irradiated cultures (Figure 3 ). The increase of p53 expression was proportional to the absorbed dose and inversely proportional to the number of viable cells. In normal tissues, p53 plays a major role in maintaining genomic integrity. In response to radiation-induced DNA damage and other types of stress, p53 is stabilized, ensuring that cells carrying genomic damage are effectively eliminated. Activation of p53 gives rise to cell cycle arrest and apoptosis. When the damage is too extensive and cannot be repaired, apoptosis takes place [21]. Previous studies had correlated apoptotic response with the amount of p53 that the cell can accumulate as a result of radiosensitive stress, a high level of p53 mRNA was detected [13,22-24]. 
According to Dainiak, p53 is highly expressed in radiation-sensitive tissues such as the hematopoietic system [25]. MacCallum et al. studied p53 protein distribution among mouse tissues, and showed that radiation sensitive tissues expressed high levels of p53 protein (spleen, thymus, bone marrow, ependyma, intestine), while tissues that were resistant to radiation, such as skeletal muscle and brain, expressed very low levels of p53 protein [26]. Up to today, the sensitivity of normal tissue is not investigated prior to radiotherapy. Generally, the principal parameters for such treatments against cancer are tumor localization and volume as well as the disease staging. Individual radiosensitivity aspects are not considered, although it is important for the effectiveness of radiotherapy $[1,27]$.

Despite its importance, p53 protein is not the only factor that determines radiosensitivity. Rare radiosensitivity syndromes which have genes involved in the detection of DNA damage or DNA repair (e.g. Ataxia-telangiectasia, Nijmegen breakage, Fanconi's anemia and Bloom syndrome) or excessive intoxication (e.g. alcohol and/or nicotine) can increase the sensitivity to ionizing radiation in patients undergoing radiotherapy $[1,28]$. Healthy individuals without genetic disorders also present adverse effects after irradiation of normal tissues probably, due to intrinsic genetic factors that determine the cellular response to the damage produced by IRs, in particular to the DNA molecule.

If an individual radiosensitivity could be predicted, side effects would be minimized after radiotherapy. In this scenario, the choice of the reference tissue for individual radiosensitivity is very important. Studies have suggested that the relative radiosensitivity of different types of cells from the same individual is similar, reflecting a common determinant of radiosensitivity [2933]. Thus, on the basis of this assumption, one may expect that a shift in the level of p53 protein expression related to the radiosensitivity of lymphocytes could be similarly reflected in any other cells of the same subject.

\section{CONCLUSIONS}

In this study, the rate of individual cell death assessed in irradiated PBMCs $72 \mathrm{~h}$ after culture in vitro without stimulation was proportional to the levels of $\mathrm{p} 53$ expression in lymphocytes and inversely proportional to the number of viable cells. The preliminary results presented in this work stressed the increase of p53 protein expression in lymphocytes with radiation doses. The use of p53 as a bioindicator to predict individual radiosensitivity could certainly improve the effectiveness of radiotherapy by personalizing treatment. However, further studies are needed, with a greater number of subjects and, as second step, clinical follow-up is necessary in order to compare previous radiotherapy analysis of individual p53 expression levels with post-irradiation side effects.

\section{ACKNOWLEDGEMENTS}

The authors would like to thank the Centro de Pesquisas Aggeu Magalhães (Fiocruz-CPqAM-Brazil), Centro de Radioterapia de Pernambuco (CERAPE-Brazil), Fundação de Hematologia e Hemoterapia de Pernambuco (HEMOPE-Brazil)—for providing laboratory facilities; Conselho Nacional de Desenvolvimento Científico e Tecnológico (CNPq-Brazil) for financial support. We warmly acknowledge Thaísa Feliciano de Souza, Maria Amélia Batista Neves, Valéria do Rêgo Pereira, Virginia Lorena, Jonathan Melo and Alexandre Parísio for technical contributions.

\section{REFERENCES}

[1] Barnett, G.C., West, C.M.L., Dunning, A.M., Elliott, R.M., Coles, C.E., Pharoah, P.D.P. and Burnet, N.G. (2009) Normal tissue reactions to radiotherapy: Towards tailoring treatment dose by genotype. Nature Reviews, $\mathbf{9}$, 134-142. doi:10.1038/nrc2587

[2] Popanda, O., Marquardta, J.U., Chang-Claude, J. and Schmezer, P. (2008) Genetic variation in normal tissue toxicity induced by ionizing radiation. Mutatation $R e$ search, 667, 58-69. doi:10.1016/j.mrfmmm.2008.10.014

[3] Borgmann, K., Röper, B., El-Awady, R.A., Brackrock, S., Bigalke, M., Dörk, T., Alberti, W., Dikomey, E. and Dahm-Daphi, J. (2002) Indicators of late normal tissue response after radiotherapy for head and neck cancer: Fibroblasts, lymphocytes, genetics, DNA repair, and chromosome aberrations. Radiotherapy Oncology, 64, 141-152. doi:10.1016/S0167-8140(02)00167-6

[4] Borgmann, K., Hoeller, U., Nowack, S., Bernhard, M., Röper, B., Brackrock, S., Petersen, C., Szymczak, S., Ziegler, A., Feyer, P., Albert, W. and Dikomey, E. (2008) Individual radiosensitivity measured with lymphocytes may predict the risk of acute reaction after radiotherapy. International Journal of Radiation Oncology Biology Physics, 71, 256-264. doi:10.1016/j.ijrobp.2008.01.007

[5] Turesson, I., Nyman, J., Holmberg, E. and Oden, A. (1996) Prognostic factors for acute and late skin reactions in radiotherapy patients. International Journal of Radiation Oncology Biology Physics, 36, 1065-1075. doi:10.1016/S0360-3016(96)00426-9

[6] Twardella, D. and Chang-Claude, J. (2002) Studies on radiosensitivity from an epidemiological point of viewOverview of methods and results. Radiotherapy Oncology, 62, 249-260. doi:10.1016/S0167-8140(01)00491-1

[7] Gatti, R.A. (2001) The inherited basis of human radiosensitivity. Acta Oncologica, 40, 702-711. doi: $10.1080 / 02841860152619115$

[8] Oren, M. (2003) Decision making by p53: Life, death and cancer. Cell Death and Differentiation, 10, 431-442. doi: $10.1038 /$ sj.cdd. 4401183

[9] Yee, K.S. and Vousden, K.H. (2005) Complicating the complexity of p53. Carcinogenesis, 26, 1317-1322. doi:10.1093/carcin/bgi122

[10] Jänicke, R.U., Sohn, D. and Schulze-Osthoff, K. (2008) The dark side of a tumor suppressor: Anti-apoptotic p53. 
Cell Death and Differentiation, 15, 959-976. doi:10.1038/cdd.2008.33

[11] Levine, A.J. (1997) P53 the cellular gatekeeper for growth and division. Cell, 88, 323-331. doi:10.1016/S0092-8674(00)81871-1

[12] Drané, P., Alvarez, S., Meiller, A. and May, E. (2002) L'activation de la protéine p53, un événement déterminant de la réponse cellulaire aux radiations ionisantes. Médecine Nucléaire Imagerie Fonctionnelle et Métabolique, 26, 139-147.

[13] Fei, P. and El-Deiry, W.S. (2003) P53 and radiation responses. Oncogene, 22, 5774-5783. doi:10.1038/sj.onc.1206677

[14] Cavalcanti Júnior, G.B.M., Scheiner, A.M., Oliveira, J.G.P., Vasconcelos, F.C., Ferreira, A.C.S. and Maia, R.C. (2003) Citometria de fluxo, imunocitoquímica e western blot na detecção da expressão da proteína p53 em células tumorais: Uma análise comparative. Revista Brasileira de Análises Clínicas, 35, 125-142.

[15] Cavalcanti, M.B., Amaral, A.J., Fernandes, T.S., Melo, J.A. and Machado, C.G.F. (2008) P53 protein expression levels as bioindicator of individual exposure to ionizing radiation by flow cytometry. Molecular and Cellular Biochemistry, 308, 127-131. doi:10.1007/s11010-007-9620-5

[16] Bacal, N.S. and Faulhaber, M.H.W. (2003) Aplicação prática em citometria de fluxo. Atheneu, São Paulo.

[17] Boreham, D.R., Gale, K.L., Maves, S.R., Walker, J.-A. and Morrison, D.P. (1996) Radiation-induced apoptosis in human lymphocytes: Potential as a biological dosimeter. Health Physics, 71, 685-691. doi:10.1097/00004032-199611000-00007

[18] Seki, H., Iwai, K., Kanegane, H., Konno, A., Ohta, K., Ohta, K., Yachie, A., Taniguchi, N. and Miyawaki, T. (1995) Differential protective action of cytokines on radiation-induced apoptosis of peripheral lymphocytes subpopulations. Cellular Immmunology, 163, 30-36. doi:10.1006/cimm.1995.1095

[19] Schnarr, K., Dayes, I., Sathya, J. and Boreham, D. (2007) Individual radiosensitivity and its relevance to health physics. Dose Response, 5, 333-348. doi:10.2203/dose-response.07-022.Schnarr

[20] Borgmann, K., Dikomey, E., Petersen, C., Feyer, P. and Hoeller, U. (2009) Sex-specific aspects of tumor therapy. Radiation Environmental Biophysics, 48, 115-124. doi:10.1007/s00411-009-0216-1

[21] Guerquin, M.-J., Duquenne, C., Coffigny, H., RouillerFabre, V., Lambrot, R., Bakalska, M., Frydman, R., Habert, R. and Livera, G. (2008) Sex-specific differences in fetal germ cell apoptosis induced by ionizing radiation. Human Reproduction, 24, 670-678. doi:10.1093/humrep/den410

[22] Alsbeih, G., El-Sebaie, M., Al-Rajhin, N., Allam, A., Al-buhairi, M., Al-Harbi, N., Khafaga, Y., Alsubael, M. and Al-Shabanah, M. (2004) Relationship between radiosensitivity and normal tissue complications in Saudi cancer patients treated with radiotherapy. Journal of the
Egyptian National Cancer Institute, 16, 216-223.

[23] Gudkov, A.V. and Komarova, E.A. (2003) The role of p53 in determining sensitivity to radiotherapy. Nature Reviews Cancer, 3, 117-129. doi:10.1038/nrc992

[24] Murray-Zmijewski, F., Lane, D.P. and Bourdon, J.C. (2006) P53/p63/p73 isoforms: An orchestra of isoforms to harmonise cell differentiation and response to stress. Cell Death and Differentiation, 13, 962-972. doi:10.1038/sj.cdd.4401914

[25] Dainiak, N. (2002) Hematologic consequences of exposure to ionizing radiation. Experimental Hematology, 30, 513-528. doi:10.1016/S0301-472X(02)00802-0

[26] MacCallum, D.E., Hupp, T.R., Midgley, C.A., Stuart, D., Campbell, S.J., Harper, A., Walsh, F.S., Wright, E.G., Balmain, A., Lane, D.P. and Hall, P.A. (1996) The p53 response to ionising radiation in adult and developing murine tissues. Oncogene, 13, 2575-2587.

[27] Hall, E.J. and Giaccia, A.J. (2006) Radiosensitivity and cell age in the mitotic cycle. In: Radiobiology for the Radiologist, 6th Edition, Lippincott Wilkins \& Williams, Philadelphia, 47-59.

[28] Greve, B., Dreffke, K., Rickinger, A., Könemann, S., Fritz, E., Eckardt-Schupp, F., Amler, S., Sauerland, C., Braselmann, H., Sauter, W., Illig, T., Schmezer, P., Gomolka, M., Willich, N. and Bölling, T. (2009) Multicentric investigation of ionising radiation-induced cell death as a predictive parameter of individual radiosensitivity. Apoptosis, 14, 226-235. doi:10.1007/s10495-008-0294-6

[29] Guirado, D. and Almodóvar, J.M.R. (2003) Prediction of normal tissue response and individualization of doses in radiotherapy. Physics in Medicine and Biology, 48, 3213-3223. doi:10.1088/0031-9155/48/19/008

[30] Ramsay, J. and Birrell, G. (1995) Normal tissue radiosensitivity in breast cancer patients. International Journal of Radiation Oncology Biology Physics, 31, 339-344. doi:10.1016/0360-3016(94)00478-4

[31] Ozsahin, M., Ozsahin, H., Shi, Y., Larsson, B., Würgler, F.E. and Crompton, N.E.A. (1997) Rapid assay of intrinsic radiosensitivity based on apoptosis in human $\mathrm{CD} 4$ and CD8 T-lymphocytes. International Journal of Radiation Oncology Biology Physics, 38, 429-440. doi:10.1016/S0360-3016(97)00038-2

[32] Núñez, M.I., Guerrero, M.R., López, E., Del Moral, M.R., Valenzuela, M.T., Siles, E., Villalobos, M., Pedraza, V., Peacock, J.H. and Ruiz de Almodóvar, J.M. (1998) DNA damage and prediction of radiation response in lymphocytes and epidermal skin human cells. International Journal of Cancer, 76, 354-361. doi:10.1002/(SICI)1097-0215(19980504)76:3<354::AID -IJC12>3.0.CO;2-B

[33] West, C.M., Davidson, S.E., Elyan, S.A., Swindell, R., Roberts, S.A., Orton, C.J., Coyle, C.A., Valentine, H., Wilks, D.P., Hunter, R.D. and Hendry, J.H. (1998) The intrinsic radiosensitivity of normal and tumor cells. International Journal of Radiation Oncology Biology Physics, 73, 409-413. 